\title{
EFEKTIVITAS METODE RESITASI PADA PEMBELAJARAN MENULIS PUISI
}

\author{
Andi Sutisno \\ e-mail: aksraabdikata@gmail.com
}

\begin{abstract}
ABSTRAK
Tujuan penelitian ini untuk mengetahui hasil belajar siswa kelas X SMA Negeri 1 Tukdana Tahun Pelajaran 2016/2017 dalam menulis puisi menggunakan metode resitasi.Pembahasan yang dikaji dalam penelitian ini dapat dirumuskan sebagai berikut.(1) Bagaimana kemampuan menulis puisi siswa kelas X SMA Negeri 1 Tukdana Tahun Pelajaran 2016/2017 sebelum pembelajran dengan metode resitasi? (2) Bagaimana kemampuan menulis puisi siswa kelas X SMA Negeri 1 Tukdana Tahun Pelajaran 2016/2017 sesudah pembelajran dengan metode resitasi? (3) Apakah metode resitasi efektif digunakan dalam pembelajaran menulis puisi siswa di kelas X SMA Negeri 1 Tukdana Tahun Pelajaran 2016/2017?

Metode yang digunakan dalam penelitian ini adalah metode eksperimen. Desain penelitian yang digunakan yaitu one-group pretest-posttest design. Metode eksperimen ini dilakukkan untuk menguji coba pembelajaran menulis puisi dengan metode resitasi. Populasi dalam penelitian ini adalah siswa kelas X SMA Negeri 1 Tukdana Tahun Pelajaran 2016/2017 yang terdiri atas delapan kelas, sedangkan sampel yang diambil adalah kelas X-5 dengan jumlah 26 siswa.

Hasil penelitian menunjukan kemampuan menulis puisi siswa kelas $\mathrm{X}-5$, nilai pretestsebesar 68,65dan nilai post-test sebesar 82,11. Jadi, terdapat kenaikan sebesar 13,46. Berdasarkan penghitunan uji-t, di peroleh $t_{\text {hitung }} 6,47$ dan $t_{\text {tabel }} 1,706$ karena nilai $t_{\text {hitung }}$ lebih besar dari $t_{\text {tabel }}$ 6,47>1,706 maka Ho ditolak dan Ha diterima. Dengan demikian dapat disimpulkan bahwa metode resitasi efektif dalam pembelajaran menulis puisi siswa kelas X-5 SMA Negeri 1 Tukdana Tahun Pelajaran 2016/2017.

Pemanfaatan metode pembelajaran terutama metode resitasi bisa digunakan dalam pembelajaran menulis puisi serta materi lain yang membutuhkan waktu lama untuk mengerjakan latihan. Metode resitasi bisa digunakan oleh guru dalam pembelajaran menulis puisi. Diharapkan bagi peneliti selanjutnya, mengembangkan metode-metode pembelajaran yang lebih efektif dan inovatif dalam belajar mengajar.
\end{abstract}

Kata Kunci:menulis puisi, metode resitasi, dan efektivitas pembelajaran.

\section{A. PENDAHULUAN}

Kurikulum memiliki kedudukan yang sangat penting dalam sistem pendidikan, karena kurikulum mengarah pada proses dan tercapainya tujuan pembelajaran. Bahasa Indonesia adalah bahasa Nasional yang mempunyai fungsi sebagai pemersatu bangsa, sehingga sebagai warga Negara berkewajiban mempelajari bahasa Indonesia.Bahasa Indonesia dalam dunia pendidikan telah diberikan dari mulai tingkat dasar sampai perguruan tinggi. Bahasa merupakan suatu alat yang digunakan dalam kegiatan berkomunikasi. Sedangkan sastra, menurut Semi (1988: 8) adalah bentuk dan hasil pekerjaan seni kreatif yang objeknya adalah manusia dan kehidupannya menggunakan bahasa sebagai mediumnya.

Karya sastra menjadi bagian yang tidak terpisahkan dalam perjalanan budaya dan peradaban karya cipta manusia itu 
sendiri. Banyak sekali jenis karya sastra seperti puisi, novel dan drama. Pengajaran sastra menurut Rusyana (1982: 5-6) termasuk ke dalam pengajaran yang sudah tua umurnya, dan hingga sekarang masih bertahan dalam kurikulum pengajaran di sekolah. Bertahannya pengajaran sastra dalam kurikulum sekolah, tentulah disebabkan oleh nilai pengajaran sastra untuk mencapai tujuan pendidikan. Pengajaran sastra mempunyai peranan dalam mencapai berbagai aspek dan tujuan pendidikan dan pengajaran, seperti pendidikan susila, sosial perasaan, sikap penilaian, dan keagamaan.

Belajar sastra pada dasarnya adalah belajar bahasa dalam praktik. Bahasa dibagi menjadi dua yaitu, bahasa lisan dan tulisan. Bahasa yang dipakai seseorang akan ikut mencerminkan pikirannya.Ketrampilan berbahasa mempunyai empat komponen yaitu keterampilan menyimak (listening skills), keterampilan berbicara (spiking skills), keterampilan membaca (reading skills), keterampilan menulis (writing skills) (Tarigan, 2008:1). Keterampilan menulis memegang peranan yang sangat penting dalam kehidupan manusia selain keterampilan berbicara. Menurut Henry Guntur Tarigan (2008: 3) mengatakan menulis merupakan suatu keterampilan berbahasa yang dipergunakan untuk berkomunikasi secara tidak langsung, tidak tatap muka dengan orang lain. Menulis merupakan suatu kegiatan yang produktif dan ekspresif.

Dalam pelajaran Bahasa Indonesia terdapat dua aspek yang dipelajari, yaitu aspek kebahasaan dan sastra.Pada aspek sastra, siswa diharapkan dapat memahami sastra bukan hanya membaca karya yang ada di dalam buku pelajaran saja tetapi dapat membuat karya sastra, seperti menulis novel, puisi, naskah drama, dan lain-lain. Pendidikan sastra adalah pendidikan yang mencoba untuk mengembangkan kompetensi apresiasi sastra, kritik sastra dan proses kreatif sastra. Dalam hal ini, proses kreatif sastra lebih ditekankan oleh peneliti kepada siswa agar dapat menulis sebuah puisi dengan sekreatif mungkin,contohnya dalam lingkungan sekolah atau perguruan tinggi. Adanya kolaborasi antar genre seni, seperti seni musik dengan seni sastra (puisi), akan menghasilkan karya-karya kreatif. Usaha menghasilkan karya-karya kreatif yang berupa puisi, baik yang berkolaborasi menjadi lirik lagu maupun yang independen sebagai puisi dapat melalui kegiatan menulis kreatif karya sastra berbentuk puisi.

Kegiatan menulis puisi itu sendiri tidak datang dengan sendirinya melainkan melalui proses. Proses menghasilkan karya puisi dapat melalui kegiatan menyimak dan membaca terlebih dahulu yang hanya mencakup aspek kognitif saja. Adapun pembelajaran mengapresiasi dan memproduksi karya sastra (melalui kegiatan menulis karya sastra) yang mencakup tidak dipungkiri bahwa puisi adalah seni yang bermediakan bahasa. Pengajaran bahasa dan sastra, di sekolah diberikan empat jenis keterampilan berbahasa.Keempat jenis keterampilan tersebut adalah menyimak, berbicara, membaca, dan menulis. Penguasaan keterampilan berbahasa tersebut terjadi secara bertahap. Awalnya, anak mengenal bahasa melalui menyimak. Setelah menyimak, anak tersebut berusaha untuk berbicara menirukan bahasa yang disimak. Tahap berikutnya, anak akan berlatih membaca dan berusaha untuk mengenal bentuk tulisan (wacana). Setelah itu, ia akan berusaha untuk menulis. Diantara keempat keterampilan berbahasa tersebut memiliki keterkaitan yang erat. Hubungan antar jenis keterampilan berbahasa ini sangat berkaitan dengan proses penciptaan puisi.

Menulis merupakan kegiatan yang mencurahkan segala pikiran dan imajinasi seseorang menjadi tulisan. Praktik dari kegiatan menulis salah satunya adalah puisi. Menulis puisi bukan perkara mudah melainkan harus sering dilatih atau kita sering membuat puisi, entah dengan pengalaman yang kita alami sendiri atau pengalaman orang lain yang kita baca atau 
kita dengarkan. Kenyataan menulis puisi para siswa menurut Rusyana (1982: 32) dalam memilih puisi pun kita mempertimbangkan lingkungan anak, siswa lebih memahami apa yang dikenalnya. Hal lain yang kita perhatikan dalam memilih puisi bagi siswa adalah dari segi bahasanya. Bahasa puisi harus ada pada taraf kemampuan siswa, bahasa yang digunakan dalam membuat puisi harus mencirikan bahasa sastra.

Proses kreatif menulis puisi juga berkaitan dengan kegiatan membaca, utamanya membaca kreatif. Menurut Harras dan Sulistyaningsih (1997:230), membaca kreatif memerlukan pencermatan ide-ide yang dikemukakan penulis, kemudian dibandingkan dengan ide-ide sejenis yang mungkin berbeda. Membaca akan menambah wawasan seseorang sehingga mendapat ide baru yang diaplikasikan dalam bentuk aktivitas meningkatkan kualitas menulis.Aktivitas yang dimaksud setelah membaca adalah kegiatan menulis puisi berdasarkan ide-ide yang didapatkan dari bahan bacaan.

Memberikan pembelajaran menulis puisi diperlukan strategi pengajaran yang terdiri atas metode dan teknik atau prosedur yang menjamin siswa mencapai tujuan pembelajaran. Penggunaan metode pengajaran merupakan salah satu faktor yang mempengaruhi tercapainya tujuan pembelajaran. Menurut Hamdani metode pembelajaran adalah cara yang digunakan guru untuk menyampaikan pelajaran kepada siswa (2011:80). Ketepatan penggunaan metode pembelajaran bergantung pada kesesuaian metode pembelajaran dengan beberapa faktor yaitu tujuan pembelajaran, materi pembelajaran, kemampuan guru, kondisi siswa, sumber atau fasilitas, situasi dan kondisi waktu. Bermacam-macam metode pembelajaran, salah satunya adalah metode resitasi.Soekartawi (1995: 19) mendefinisikan bahwa metode resitasi adalah suatu cara yang menyajikan bahan pelajaran dengan memberikan tugas kepada siswa untuk dipelajari yang kemudian dipertanggungjawabkan di depan kelas.Kekuatan metode resitasidalam Pembelajaran menulis puisi bemberian tugas kepada siswa tugas-tugas ini yang nantinya akan membuat siswa belajar, kelebihan metode resitasi yaitu pengetahuan yang anak didik peroleh dari hasil belajar sendiri akan dapat diingat lebih lama, dan anak didik berkesempatan memupuk perkembangan dan keberanian mengambil inisiatif, bertanggung jawab dan beriri sendiri (Djamarah dalam Hariawan, dkk., 2012:86).

Metode ini sebelumnya juga pernah dilakukan pada penelitian mengenai pembelajaran menulis puisi oleh Aulia Perbiana Puspasari (2013) yaitu tentang Kemampuan Menulis Puisi dengan Teknik Pemberian Tugas/Resitasi. Data penelitian ini diambil dari hasil tes tertulis dengan subjek penelitian Siswa Kelas VII SMPN 2 Tangerang Tahun Pelajaran 2013/2014. Melalui penelitian tersebut penggunaan metode resitasi efektif dalam pembelajaran menulis puisi. Hal tersebut dapat dilihat dari hasil akhir rata-ratanya. Kemampuan menulis puisi dengan menggunakan teknik pemberian tugas/resitasi mendapatkan hasil yang baik pada siswa kelas VIII SMPN 2 Tangerang Selatan. Siswa menulis puisi sebelum menggunakan teknik pemberian tugas/resitasi belum mendapatkan hasil yang baik yaitu nilai rata-rata siswa mendapatkan 67,2. Sedangkan menulis puisi setelah menggunakan teknik pemberian tugas/resitasi sudah mendapatkan hasil yang baik yaitu nilai rata-rata siswa mendapatkan 74,1. Dari hasil angket dapat dilihat bahwa 25 siswa atau $59,5 \%$ siswa suka menulis puisi dan 22 siswa atau 52,39\% siswa menyukai pembelajaran di luar kelas.

Sehubungan dengan penjelasan diatas, penulis akan mencoba menggunakan metode resitasi dalam pembelajaran menulis puisi. Penulis ingin mengetahui hasil belajar siswa dalam pembelajaran menulis puisi dengan menggunakan metode resitasi untuk kelas X. Meliputi Pemilihan tema, pemilihan kata, imajinasi, dan pengalaman yang pernah 
dialami atau dilihat oleh siswa, siswa akan

\section{B. TEORI KAJIAN}

\section{Pengertian Pembelajaran}

Bagi seorang guru mengajar merupakan aktifitas utama. Pembelajaran merupakan salah satu unsur penentu baik tidaknya lulusan yang dihasilkan oleh suatu sistem pendidikan. Pembelajaran ibarat jantung dari proses pendidikan (Jamal Ma'mur Asmani, 2011 : 17). Pembelajaran adalah usaha yang dilakukan oleh pendidik untuk membelajarkan peserta didik yang pada akhirnya terjadi perubahan prilaku (Muhammad Fathurrohman, 2015:18). Menurut E. Kosasih (2015:11), pembelajaran diartikan sebagai suatu usaha yang sengaja melibatkan dan menggunakann pengaruh profesional yang dimiliki guru untuk menjadikan seseorang bisa mencapai tujuan kurikulum, definisi ini pun terdapat dua variabel yang bermuara pada kegiatan belajar mengajar, yakni.

1) Usaha yang sengaja melibatkan dan menggunakan pengetahuan profesional yang dimiliki guru (mengajar).

2) Menjadikan seseorang bisa mencapai tujuan kurikulum (belajar).

Jelaslah bahwa pembelajaran merupakan istilah lain untuk proses belajar mengajar.

Definisi lain pembelajaran menurut Moh. Uzer Usman (2000: 4) yang dikutip oleh Moh. Sholeh Hamid (2014: 207) pembelajaran merupakan sebuah proses yang mengandung serangkaian perbuatan guru dan siswa atas dasar hubungan timbal balik, yang berlangsung dalam situasi edukatif untuk mencapai tujuan tertentu.

$$
\text { Definisi pembelajaran dalam }
$$
penelitian ini adalah usaha yang terpenting dalam proses pendidikan, ketika proses pembelajaran berjalan baik maka akan baik pula lulusan yang dihasilkan serta proses ini juga melibatkan pendidik dan peserta didik untuk mencapai tujuan yang ingin dicapai mengubahnya kedalam bentuk puisi.

\section{Pengertian Menulis Puisi}

Menulis puisi merupakan kegiatan membuat karya sastra yang dilakukan seseorang untuk mengungkapkan pikiran, perasaan dan imajinasi untuk menuangkannya kedalam bentuk karya sastra berupa tulisan. Menurut Saini (1993: 153-154) menulis puisi yaitu,

Menulis puisi dapat membuat seseorang menggunakan katakata secara konotatif, menyusun irama dan bunyi, menyusun baris-baris dan bait-bait dengan memperhatikan pengilangan dan tipografi yang dapat mengungkapkan pikiran dan perasaan, sedangkan penyair pemula (siswa) berusaha sebaikbaiknya menulis apa yang ada dalam hatinya dengan jelas dan kongkrit.

Sedangkan pendapat lain mengungkapkan menulis puisi menurut Jabrohim (2009: 67-68) menyatakan bahwa menulis puisi yaitu,

Merupakan suatu kegiatan seorang intelektual, yakni kegiatan yang menuntut seseorang harus benar-benar cerdas, harus benar-benar mengusai bahasa, harus luas wawasannya, dan peka perasaannya. Mengimajikan atau mengembangkan fakta empirik menjadi sebuah puisi, penulis puisi harus pula memahami unsur-unsur pembangun puisi, serta mampu memanfaatkannya sebagai wahana untuk menampilkan bobot puisi yang ditulisnya.

Intinya ketika seseorang menulis puisi cara sesorang mengungkapkan isi hatinya kedalam sebuah karya, namun 
mereka harus sudah memahami unsur-unsur yang terkandung didalam puisi dan mereka juga harus benar-benar mengusai bahasa dengan baik, serta pengimajinasian yang bagus.

\section{Langkah Menulis Puisi}

Menulis puisi bukan hal yang mudah menurut Komaidi (2007: 207) sebagai berikut. 1) sebelum menulis puisi, pahami dulu apa itu puisi. Kita dapat mencoba sebanyak mungkin membaca puisi-puisi yang dibuku, majalah atau media massa. Setelah banyak membaca puisi tersebut sedikit atau banyak kita akan tahu apa itu puisi dan bagaimana cara membuatnya. 2) mencari inspirasidengan berkeliling-keliling kealam lingkungan sekitar karena hal itu akan memperluas pengalaman estetika kita untuk dituangkan kedalam puisi. 3) cobalah membawa buku kecil kemana kita pergi. Hal ini untuk menuliskan setiap ide atau inspirasi berharga yang terlintas dipikiran kita agar tidak cepat hilang atau terlewatkan. 4) tulis apa yang ada di dalam pikiran, perasaan kita, kegelisaan kita ke bentuk kata-kata dalam puisi dengan bebas tanpa beban. 5) baca dan perbaiki puisi yang telah dibuat. Setelah menulis puisi, coba endapkan sebentar beberapa jam atau beberapa hari kemudian. Setelah itu baca lagi puisi yang dibuat, mungkin kita akan merasakan sesuatu yang berbeda dan muncul perspektif baru dalam pikiran. 6) setelah selesai menulis puisi, coba uji puisi yang dibuat untuk dikirimkan ke media massa ataupun minta kritik, saran dari orang lain sehingga puisi yang sudah dibuat menjadi semakin menarik dan mempunyai estetika yang tinggi.

Sejalan dengan pendapat di atas Kosasih (2007: 67) mengungkapkan langkah-langkah menulis puisi sebagai berikut.

1) Tentulah pengalaman yang paling menarik yang bisa ditulis menjadi puisi. Jadi sebelum menulis puisi siswa harus mengingat kembali pengalaman yang paling menarik dan berkesan yang pernah dialami.

2) Kemudian siswa mulai menulis pengalaman-pengalaman itu kedalam baris-baris puisi dengan menggunakan kata-kata yang padat. Setelah siswa menentukkan pengalaman yang berkesan barulah siswa menentukkan idenya dengan menuliskan baris-baris puisi.

3) Pilih kata-kata yang bermakna kias atau konotasi yang bisa menjadi simbol atau lambang dari hal-hal yang diceritakan dalam sebuah puisi tersebut. Siswa diharapkan bisa memilih kata-kata yang indah dalam menulis puisi.

4) Setelah itu berlatih terus menerus untuk menulis puisi yang baik. Siswa diharapkan terus berlatih dalam menulis puisi, agar hasil puisinya lebih baik, dan

5) Beranikanlah mempublikasikan puisimu kemajalah dingding atau mengirimkan kemedia massa. Jangan merasa tidak percaya diri terhadap hasil yang kita peroleh.

Langkah membuat puisi hasil simpulan penulis melihat dari Komaidi dan Kosasih sebagai berikut.

1) Memahami apa itu puisi.

2) Sering membaca puisi karya orang lain.

3) Mecari inspirasi tentang sesuatu yang ingin di jadikan puisi entah itu pengalaman yang pernah dialami ataupun objek tertentu.

4) Pahami unsur-unsur di dalam puisi.

5) Pahami pemilihan kata dan tanda baca yang tepat untuk membuat puisi

6) Sering membuat puisi dan baca kembali setelah beberapa hari agar kita bisa memperbaiki kata yang kurang tepat.

7) Coba menunjukan keteman untuk meminta saran atau kritik tentang puisi yang kita buat, bisa juga kita mengirimkan puisi kita ke media massa. 


\section{Metode Resitasi}

\section{Pengertian Metode Pembelajaran}

Metode pembelajaran merupakan salah satu serangkaian dari kegiatan pembelajaran mengajar. Hamdani (2011:80)mengatakan bahwa, "metode pembelajaran ialah cara yang digunakan guru untuk menyampaikan pembelajaran kepada siswa". Sedangkan menurut Hamzah (2012:16) mengemukakan bahwa, "metode pembelajaran didefinisikan sebagai caracara yang berbeda untuk mencapai pembelajaran yang berbeda dibawah kondisi pembelajaran yang berbeda". Variabel metode pembelajaran diklasifikasikan lebih lanjut menjadi tiga jenis, yaitu:

1) strategi pengorganisasian (organizational strategy);

2) strategi penyampaian (delivery strategy); dan

3) Strategi pengelolaan (managemnt strategi).

Organizational strategy adalah metode untuk mengorganisasikan isi bidang studi yang telah dipilih untuk pembelajaran. delivery strategy adalah metode untuk menyampaikan pembelajaran kepada siswa dan atau menerima serta merespon masukan yang berasal dari siswa. Media pembelajaran merupakan bidang kajian utama dari strategi ini. Managemnt Strategi adalah metode untuk menata interaksi antar belajar dan variabel metode pembelajaran lainnya, variabel strategi pengorganisasian dan isi pembelajaran. Sumber lain yaitu diktat Depertemen Agama RI yang dikutip oleh Hamdani (2011:80) menyebutkan bahwa, "Metode pembelajaran merupakan alat untuk menciptakan proses belajar mengajar".

Definisi metode pembelajaran dalam penelitian ini adalah proses belajar mengajar dengan menggunakan cara yang menopang untuk menyampaikan materi kepada siswa.

\section{Pengertian Metode Resitasi}

Metode Resitasi (penugasan) adalah cara penyajian bahan pelajaran di mana guru memberikan tugas tertentu agar siswa melakukan kegiatan belajar (Sudirman. N, 1991: 141). Metode resitasi adalah cara penyajian pembelajaran dimana guru memberikan tugas tertentu agar murid melakukan kegiatan belajar, kemudian harus dipertanggungjawabkan, tugas yang diberikan oleh guru dapat memperdalam bahan pelajaran, dan dapat juga mengecek bahan yang telah dipelajari, tugas dan resitasi merangsang anak untuk aktif belajar baik secara individual maupun kelompok (Syaiful Sagala, 2013: 219). Slameto (1990:115) mengemukakan Metode Resitasi terstruktur adalah cara penyampaian bahan pelajaran dengan memberikan tugas kepada siswa untuk dikerjakan dalam rentangan waktu tertentu dan hasilnya harus dipertanggungjawabkan kepada guru. Sedangkan menurut Moh.Sholeh Hamid (2014: 213) pemberian tugas adalah guru memberikan suatu tugas kepada siswa dan mengaitkannya dengan tugas-tugas yang lain. Definisi lain tentang metode resitasi yaitu suatu metode mengajar dimana siswa diharuskan membuat resume dengan kalimat tersendiri (Adang Heriawan, dkk, 2012: 86).

Definisi metode resitasi dalam penelitian ini adalah kegiatan pembelajaran dimana guru memberikan tugas kepada siswa agar siswa berpikir dalam waktu tertentu serta siswa dapat menpertanggungjawabkan hasil dari tugasnya.

\section{Prinsip-prinsip Metode Resitasi}

Setiap pembelajaran mempunyai tujuan pembelajaran yang harus dicapai oleh siswa setelah pembelajaran tersebut, metode pemberian tugas perlu memperhatikan, mengarahkan, dan membimbing siswa. Mengenai hal ini, untuk melatih rasa tanggung jawab siswa terhadap tugas yang diberikan. Sedangkan menurut Djamarah dan Zain (2010: 85) memaparkan tentang prinsip metode resitasi secara gamblang bahwa metode resitasi pertanggungjawaban siswa dengan cara melaporkan atau mengumpulkan tugas yang telah diberikan 
baik dalam bentuk lisan maupun turtulis inilah yang disebut resitasi.

Penulis menyimpulkan bahwa Inti dari prinsip metode resitasi yaitu melatih rasa tanggungjawab siswa yang telah diberikan guru, baik dalam bentuk lisan atau tulisan dengan cara melaporkan atau mengumpulkan hasil pekerjaannya.

\section{Langkah-langkah Metode Resitasi}

Langkah-langkah metode resitasi menurut Asmani (2011: 35) bahwa guru bertugas menyuruh anak didiknya untuk mengerjakan tugas yang telah diberikan untuk menyelesaikan atau mempertanggungjawabkan. Menurut Djamarah dan Zain (2010: 86) langkahlangkah metode resitasi sebagai berikut.

1) Fase pemberian tugas

Tugas yang diberikan kepada siswa hendaknya mempertimbangkan hal-hal berikut. 1) tujuan yang akan dicapai, 2) jenis tugas yang jelas dan tepat sehingga anak mengerti apa yang ditugaskan tersebut, 3) ada petunjuk dan sumber yang dapat membantu pekerjaan siswa, 4) sediakan waktu yang cukup untuk mengerjakan tugas tersebut.

2) Langkah pelaksanaan tugas

Langkah pelaksanaannya guru mengamati apa yang sedang dikerjakan siswa atau guru mengetahui pemahaman siswa tentang tugas yang diberiakan. Langkahnya yaitu, 1) diberikan bimbingan/pengawasan oleh guru, 2) diberikan dorongan supaya anak mau bekerja, 3) dianjurkan agar siswa mencatat hasil-hasil yang ia peroleh dengan baik dan sistematis.

3) Fase mempertanggungjawabkan tugas

Langkah selanjutnya, siswa memberikan laporan entah lisan atau tulisan tugas yang telah dikerjakan. Tahapan ini siswa mempertanggungjawabkan tugas yang diberikan oleh guru kepadanya pada pertemuan sebelumnya di kumpulkan. Setelah itu guru bisa menyimpulkan apakah tujuan pembelajaran yang disampaikan tercapai atau tidak.

\section{Kelebihan dan Keterbatasan Metode Resitasi}

Setiap metode memiliki kelebihan dan keterbatasan didalamnya, menurut Djamarah dan Zain (2010: 87) metode resitasi mempunyai kelebihan sebagai berikut.

1) Lebih merangsang siswa dalam melakukan aktivitas belajar individual ataupun kelompok.

2) Dapat mengembangkan kemandirian siswa di luar pengawasaan guru.

3) Dapat membina tanggungjawab dan disiplin siswa.

4) Dapat mengembangkan kreatifitas siswa.

Pendapat ini juga sepemahaman dengan pendapat Asmani (2011: 35) yang mengungkapkan bahwa kelebihan metode resitasi adalah:

1) pengetahuan yang anak didik peroleh dari hasil belajar sendiri akan dapat diingat lebih lama, dan

2) anak didik berkesempatan memupuk perkembangan dan keberanian mengambil inisiatif, bertanggung jawab, dan berdiri sendiri.

Kelebihan metode resitasi dari metode lainnya mengacu pada dua ahli Zain dan Asmani, peneliti mendefinisikan kelebihan metode resitasi adalah memupuk rasa tanggung jawab siswa atas pekerjaan yang mereka lakukan dengan menggunakan pengalaman pribadi dan belajar mandiri untuk mendapatkan hasil maksimal.

Metode resitasi juga mempunyai keterbatasan menurut (Djamarah dan Zain, 2010: 87) sebagai berikut:

1) siswa susah dikontrol jika tugas yang diberikan dikerjakan diluar kelas. 
2) jika tugas yang diberikan secara berkelompok, maka akan sulit membedakan siswa yang aktif dan yang tidak aktif.

3) tidak mudah memberikan tugas yang sesuai dengan perbedaan individu siswa.

4) sering memberikan tugas yang monoton (tidak bervariasi) dapat menimbulkan kebosanan siswa.

Keterbatasan metode resitasi sama dengan pendapat sebelumnya Djamarah dan Zain. Menurut Asmani (2011: 36) keterbatasan metode resitasi adalah sebagai berikut.

1) Terkadang anak didik melakukan penipuan, misalnya anak didik hanya meniru hasil pekerjaan orang lain tanpa mau berusaha payah mengerjakan sendiri.

\section{METODOLOGI PENELITIAN}

Metode yang digunakan dalam penelitian ini adalah metode eksperimen. Metode eksperimen suatu cara untuk mencari hubungan sebab akibat (hubungan kausal) antara dua faktor yang sengaja ditimbulkan oleh peneliti dengan mengeliminisasi atau mengurangi atau menyisihkan faktor-faktor lain yang mengganggu (Arikunto, 2010: 9). Ada beberapa jenis metode eksperimen di antaranya: (1) pre-experimental design yang terdiri dari one-shot case study, one-group pre-test post-test design dan iniact-group comparison, (2) true experimental design, (3) factorial design dan (4) quasi experimental design. Penelitian ini menggunakan metode one-group pretestposttest design.

Desain penelitian menggunakan onegroup pretest-posttest design(Arikunto, 2010: 142). Penelitian ini memerlukan satu kelas dan dua tes, dua tes ini yaitu pre-test dan post-test. Pre-test yaitu tes yang
2) Terkadang tugas itu dikerjakan orang lain tanpa pengawasaan.

3) Sukar memberikan tugas yang memenuhi penilaian individu.

Metode resitasi kelebihan dan keterbatasan, oleh karena itu untuk mengatasi keterbatasan yang terdapat didalalm metode resitasi penulis mempunyai solusi yaitu sebaiknya tugas yang diberikan harus dikerjakan oleh siswa pada saat pembelajaran berlangsung. Selain itu, agar siswa dapat mengerjakan tugasnya sendiri, guru harus mengawasi siswa pada saat mengerjakan tugas sehingga dapat melatih siswa untuk mempunyai rasa tanggungjawab dalam mengerjakan tugas yang telah diberikan baik dalam bentuk lisan atau tulisan secara sendiri.

dilakukan sebelum pembelajaran menulis puisi dengan metode resitasi, sedangkan post-tes yaitu tes yang dilakukan setelah pembelajaran menulis puisi dengan metode resitasi. Adapun desain penelitiannya adalah sebagai berikut.

$$
\mathrm{O}_{1} \times \mathrm{O}_{2}
$$

Keterangan:

$\mathrm{O}_{1} \quad$ : observasi pertama berupa pre-test atau tes awal yang dilakukan sebelum pembelajaran menulis puisi dengan metode resitasi.

$\mathrm{X}$ : treatment(pembelajaran menulis puisi dengan metode resitasi).

$\mathrm{O}_{2} \quad$ : observasi kedua berupa post-test atau tes akhir yang dilakukan setelah pembelajaran menulis puisi dengan metode resitasi. 


\section{HASIL PENELITIAN DAN PEMBAHASAN}

kemampuan menulis puisi siswa sebelum pembelajaran (pre-test)dengan sesudah pembelajaran (post-test). Pada kemampuan menulis puisi sebelum pembelajaran (pre-test), siswa dituntut untuk membuat puisi karangan sendiri sedangkan sesudah pembelajaran (post-test) dengan tema yang sudah di tentukan tentang pengalaman yang pernah dialami siswa. Hal ini dilakukan untuk mengetahui apakah ada kenaikan atau penurunan kemampuan dalam menulis puisi antara sebelum pembelajaran (pre-test) dengan sesudah pembelajaran (post-test). Penjabarannya sebagai berikut.

\section{Hasil Analisis Kemampuan Menulis PuisiSiswa Kelas X-5 SMA Negeri 1 Tukdana Tahun Pelajaran 2016/2017 Sebelum Pembelajaran dengan Metode Resitasi}

Berdasarkan uraian analisis hasil pembelajaran menulis puisi siswa kelas X-5 SMA Negeri 1 Tukdana Tahun Pelajaran 2016/2017 sebelum pembelajaran menggunakan metode resitasidapat disimpulkan sebagai berikut.

\section{Kesesuaian Tema}

Berdasarkan kesimpulan hasil analisis kemampuan siswa kelas X SMA Negeri 1 Tukdana sebelum pembelajaran menggunakan metode resitasipada aspek kesesuaian tema. 5 siswa mendapatskor 5 yaitu siswa ke-2, 3, 12, dan ke-13, serta 21 siswamendapatkan skor 25 yaitu siswa ke$1,4,5,6,7,8,9,10,11,14,15,16,17,18$, $19,20,21,22,23,24,25$, dan ke-26.

\section{Pada pengimajinasian}

Berdasarkan kesimpulan hasil analisis kemampuan siswa kelas X SMA Negeri 1 Tukdana sebelum pembelajaran menggunakan metode resitasipada aspek kesesuaian pengimajinasian . 1 siswa mendapat skor 5 yaitu siswa ke-16. 16 siswa mendapatkan skor 10 yaitu siswa ke-2, 3, $4,5,11,12,13,14,15,18,21,22,23,24$, 25, dan ke-26. 9 siswa mendapat skor 15 yaitu siswa ke-1, 6, 7, 8, 9, 10, 17, 19, dan ke-20. Serta tidak ada siswa yang mendapat skor 20.

\section{Penggunaan Gaya Bahasa}

Berdasarkan kesimpulan hasil analisis kemampuan siswa kelas X SMA Negeri 1 Tukdana sebelum pembelajaran menggunakan metode resitasipada aspek penggunaan gaya bahasa. 13 siswa mendapat skor 5 yaitu siswa ke-4. 5, 8, 9, $10,11,14,15,16,22,23,25$ dan ke-26. 11 siswa mendapatkan skor 10 yaitu siswa ke$1,3,6,7,12,13,18,19,20,21$, dan ke-24. 2 siswa mendapat skor 15 yaitu siswa ke-2, dan ke-17.

\section{Penggunaan Diksi}

Berdasarkan kesimpulan hasil analisis kemampuan siswa kelas X SMA Negeri 1 Tukdana sebelum pembelajaran menggunakan metode resitasipada aspek penggunaan diksi . 2 siswa mendapat skor 5 yaitu siswa ke-8 dan 16. Tidak ada siswa yang mendapatkan skor 10.13 siswa mendapat skor 15 yaitu siswa ke-1, 2, 6, 7, $9,10,11,18,19,23,24$, dan ke-25. 8 siswa mendapat skor 20 yaitu siswa ke-4, 5, 14, $15,17,21,22$, dan ke-26. Serta 4 siswa yang mendapat skor 25 yaitu siswa ke-3, 12, 13 , dan ke-20.

\section{Penggunaan Rima}

Berdasarkan kesimpulan hasil analisis kemampuan siswa kelas X SMA Negeri 1 Tukdana sebelum pembelajaran menggunakan metode resitasipada aspek penggunaan rima . 4 siswa mendapat skor 5 yaitu siswa ke-16, 21, 22 dan ke-26. 18 siswa mendapatkan skor 10 yaitu siswa ke$1,3,4,5,6,7,8,9,10,11,12,14,15,17$, 19, 23, 24 dan ke-25. 4 siswa mendapat skor 15 yaitu siswa ke-2, 13,18, dan ke-20.

\section{Hasil Analisis Kemampuan Menulis Puisi Siswa Kelas X-5 SMA Negeri 1 Tukdana Tahun Pelajaran 2016/2017 Setelah Pembelajaran dengan Metode Resitasi \\ Berdasarkan uraian analisis hasil pembelajaran menulis puisi siswa kelas X-5 SMA Negeri 1 Tukdana Tahun Pelajaran 2016/2017 sesudah pembelajaran}


menggunakan metode resitasidapat disimpulkan sebagai berikut.

\section{Kesesuaian Tema}

Berdasarkan kesimpulan hasil analisis kemampuan siswa kelas X SMA Negeri 1 Tukdana sesudah pembelajaran menggunakan metode resitasipada aspek kesesuaian tema. 2 siswa mendapat skor 5 yaitu siswa ke-6 dan ke-13. Serta 24 siswa mendapatkan skor 25 yaitu siswa ke-1, 2, 3, $4,5,7,8,9,10,11,12,14,15,16,17,18$, 19, 20, 21, 22, 23, 24, 25, dan ke-26.

\section{PadaPengimajinasian}

Berdasarkan kesimpulan hasil analisis kemampuan siswa kelas X SMA Negeri 1 Tukdana sesudah pembelajaran menggunakan metode resitasipada aspek kesesuaian pengimajinasian . tidak ada siswa yang mendapat skor 5. 4 siswa mendapatkan skor 10 yaitu siswa ke-18, 20, 24 dan ke-25. 12 siswa mendapat skor 15 yaitu siswa ke-2, $6,7,8,9,10,12,16,17,21,22$,dan ke-23. Serta 10 siswa yang mendapat skor ke-1, 3, 4, 5, 11, 13, 14, 15, 19 dan ke-26.

\section{Penggunaan Gaya Bahasa}

Berdasarkan kesimpulan hasil analisis kemampuan siswa kelas X SMA Negeri 1 Tukdana sesudah pembelajaran menggunakan metode resitasipada aspek penggunaan gaya bahasa. 7 siswa mendapat skor 5 yaitu siswa ke-6, 8, 9, 10, 14 dan ke22. 11 siswa mendapatkan skor 10 yaitu siswa ke-4, 5, 7, 11, 15, 16, 17, 18, 20, 23, dan ke-24. 8 siswa mendapat skor 15 yaitu siswa ke-1, 2, 3,13, 19, 21, 25, dan ke-26.

\section{Penggunaan Diksi}

Berdasarkan kesimpulan hasil analisis kemampuan siswa kelas X SMA Negeri 1 Tukdana sesudah pembelajaran menggunakan metode resitasipada aspek penggunaan diksi . tidak ada siswa yang mendapat skor 5. Tidak ada siswa yang mendapat skor 10. 1 siswa yang mendapat skor 15 yaitu siswa ke-20.5 siswa yang mendapat skor 20 yaitu ke-4, 8, 14, 15, dan ke-21. 20 siswa yang mendapat skor 25 yaitu ke-1, 2, 3, 5, 6, 7, 9, 10, 11, 12, 13, 16, 17, 18, 19, 22, 23, 24, 25, dan ke-26.

\section{Penggunaan Rima}

Berdasarkan kesimpulan hasil analisis kemampuan siswa kelas X SMA Negeri 1 Tukdana sesudah pembelajaran menggunakan metode resitasipada aspek penggunaan rima . 11 siswa mendapat skor 5 yaitu siswa ke-2, 3, 4, 6, 10, 12, 15, 21, 22, 24 dan ke-26. 12 siswa mendapatkan skor 10 yaitu siswa ke-1, 5, 8, 11, 14, 16, 17, 18, 19, 20, 23, dan ke-25.3 siswa mendapat skor 15 yaitu siswa ke-7, 9, dan ke-13.

Rekapitulasi kemampuan menulis puisi siswa kelas X-5 SMA Negeri 1 Tukdana Tahun Pelajaran 2016/2017, Sebelum Pembelajaran (Pre-test) dengan Sesudah Pembelajaran (Post-test), pembelajaran dengan metode resitas. Peneliti uraikan pada tabel berikut.

Tabel 1

Perbandingan Kemampuan Menulis Puisi Siswa Kelas X-5 SMA Negeri 1 Tukdana Tahun Pelajaran 2016/2017 Sebelum Pembelajaran (Pre-test) dan Sesudah Pembelajaran (Post-test) Dengan Metode Resitasi

\begin{tabular}{|c|c|c|c|c|c|c|c|c|c|c|c|c|c|}
\hline \multirow{3}{*}{ No. } & \multirow{3}{*}{$\begin{array}{l}\text { Nama } \\
\text { Siswa }\end{array}$} & \multicolumn{10}{|c|}{ Aspek yang di Nilai } & \multirow{2}{*}{\multicolumn{2}{|c|}{ Skor }} \\
\hline & & \multicolumn{2}{|c|}{ Tema } & \multicolumn{2}{|c|}{$\begin{array}{l}\text { Pengima- } \\
\text { jian }\end{array}$} & \multicolumn{2}{|c|}{$\begin{array}{c}\text { Gaya } \\
\text { Bahasa }\end{array}$} & \multicolumn{2}{|c|}{ Diksi } & \multicolumn{2}{|c|}{ Rima } & & \\
\hline & & $\mathbf{X}$ & $\mathbf{Y}$ & $\mathbf{X}$ & $\mathbf{Y}$ & $\mathbf{X}$ & $\mathbf{Y}$ & $\mathbf{X}$ & $\mathbf{Y}$ & $\mathbf{X}$ & $\mathbf{Y}$ & $\mathbf{X}$ & $\mathbf{Y}$ \\
\hline 1 & $\begin{array}{l}\text { Ari } \\
\text { Apriyanto }\end{array}$ & 25 & 25 & 15 & 20 & 10 & 15 & 15 & 25 & 10 & 10 & 75 & 95 \\
\hline 2 & Ayu Erita & 5 & 25 & 10 & 15 & 15 & 15 & 15 & 25 & 15 & 5 & 60 & 85 \\
\hline 3 & $\begin{array}{l}\text { Ayunda } \\
\text { Velycia }\end{array}$ & 5 & 25 & 10 & 20 & 10 & 15 & 25 & 25 & 10 & 5 & 60 & 90 \\
\hline
\end{tabular}


BAHTERA INDONESIA:

ISSN 2541-3252

Jurnal Penelitian Pendidikan Bahasa dan Sastra Indonesia

Vol. 2, No. 1, Mar. 2017

\begin{tabular}{|c|c|c|c|c|c|c|c|c|c|c|c|c|c|}
\hline 4 & Dasi'ah & 25 & 25 & 10 & 20 & 5 & 10 & 20 & 20 & 10 & 5 & 70 & 80 \\
\hline 5 & Er Rudin & 25 & 25 & 10 & 20 & 5 & 10 & 20 & 25 & 10 & 10 & 70 & 90 \\
\hline 6 & Evi Dayanti & 25 & 5 & 15 & 15 & 10 & 5 & 15 & 25 & 10 & 5 & 75 & 55 \\
\hline 7 & Iin Sunaesih & 25 & 25 & 15 & 15 & 10 & 10 & 15 & 25 & 10 & 15 & 75 & 90 \\
\hline 8 & Irna & 25 & 25 & 15 & 15 & 5 & 5 & 5 & 20 & 10 & 10 & 60 & 75 \\
\hline 9 & $\begin{array}{l}\text { Ita } \\
\text { Rahmawati }\end{array}$ & 25 & 25 & 15 & 15 & 5 & 5 & 15 & 25 & 10 & 15 & 70 & 85 \\
\hline 10 & $\begin{array}{l}\text { Lia Erfi } \\
\text { Eryana }\end{array}$ & 25 & 25 & 15 & 15 & 5 & 5 & 15 & 25 & 10 & 5 & 70 & 75 \\
\hline 11 & Mistinih & 25 & 25 & 10 & 20 & 5 & 10 & 15 & 25 & 10 & 10 & 65 & 90 \\
\hline 12 & $\begin{array}{l}\text { Moch. Azis } \\
\text { Ally }\end{array}$ & 5 & 25 & 10 & 15 & 10 & 5 & 25 & 25 & 10 & 5 & 60 & 75 \\
\hline 13 & $\begin{array}{l}\text { Muhammad } \\
\text { Gilang. R }\end{array}$ & 5 & 5 & 10 & 20 & 10 & 15 & 25 & 25 & 15 & 15 & 65 & 80 \\
\hline 14 & Novitasari & 25 & 25 & 10 & 20 & 5 & 5 & 20 & 20 & 10 & 10 & 70 & 80 \\
\hline 15 & Nur'asiyah & 25 & 25 & 10 & 20 & 5 & 10 & 20 & 20 & 10 & 5 & 70 & 80 \\
\hline 16 & $\begin{array}{l}\text { Pandu } \\
\text { Dwinata }\end{array}$ & 25 & 25 & 5 & 15 & 5 & 10 & 5 & 25 & 5 & 10 & 45 & 85 \\
\hline 17 & $\begin{array}{l}\text { Riyan } \\
\text { Prayoga }\end{array}$ & 25 & 25 & 15 & 15 & 15 & 10 & 20 & 25 & 10 & 10 & 85 & 85 \\
\hline 18 & Riyanto & 25 & 25 & 10 & 10 & 10 & 10 & 15 & 25 & 15 & 10 & 75 & 80 \\
\hline 19 & Ropisah & 25 & 25 & 15 & 20 & 10 & 15 & 15 & 25 & 10 & 10 & 75 & 95 \\
\hline 20 & $\begin{array}{l}\text { Suhendro } \\
\text { Bimantoro }\end{array}$ & 25 & 25 & 15 & 15 & 10 & 10 & 25 & 15 & 15 & 10 & 90 & 75 \\
\hline 21 & Sureni & 25 & 25 & 10 & 15 & 10 & 15 & 20 & 20 & 5 & 5 & 70 & 80 \\
\hline 22 & Tasiroh & 25 & 25 & 10 & 15 & 5 & 5 & 20 & 25 & 5 & 5 & 65 & 75 \\
\hline 23 & $\begin{array}{l}\text { Thomas } \\
\text { Suta }\end{array}$ & 25 & 25 & 10 & 15 & 5 & 10 & 15 & 25 & 10 & 10 & 65 & 85 \\
\hline 24 & Waslam & 25 & 25 & 10 & 10 & 10 & 10 & 15 & 25 & 10 & 5 & 70 & 75 \\
\hline 25 & $\begin{array}{l}\text { Wira } \\
\text { Winengsih }\end{array}$ & 25 & 25 & 10 & 10 & 5 & 15 & 15 & 25 & 10 & 10 & 65 & 85 \\
\hline \multirow[t]{3}{*}{26} & $\begin{array}{l}\text { Yuli } \\
\text { Aprilianti }\end{array}$ & 25 & 25 & 10 & 20 & 5 & 15 & 20 & 25 & 5 & 5 & 65 & 90 \\
\hline & Jumlah & 570 & 610 & 300 & 425 & 205 & 265 & 450 & 615 & 260 & 220 & $\begin{array}{l}17 \\
85\end{array}$ & $\begin{array}{l}20 \\
25\end{array}$ \\
\hline & Rata-rata & $\begin{array}{l}21 \\
92\end{array}$ & $\begin{array}{l}23 \\
46\end{array}$ & $\begin{array}{l}11 \\
53\end{array}$ & $\begin{array}{l}16 \\
34\end{array}$ & 7,88 & $\begin{array}{l}10 \\
16\end{array}$ & $\begin{array}{l}17 \\
30\end{array}$ & $\begin{array}{l}23 \\
65\end{array}$ & 10 & 7,5 & $\begin{array}{l}68, \\
65\end{array}$ & $\begin{array}{c}8,4 \\
6\end{array}$ \\
\hline
\end{tabular}

Keterangan:

$\mathrm{X} \quad$ : (pre-test)

$\mathrm{Y} \quad:($ post-test $)$

Berdasarkan tabel tersebut, diperoleh data perbandingan kemampuan menulis puisi siswa antara sebelum pembelajaran (pre-test) dengan sesudah pembelajaran (post-test) sebagai berikut.
1. Pada kesesuaian tema sebelum pembelajaran (pre-test) diperoleh nilai rata-rata 21,92, sedangkan pada sesudah pembelajaran (post-test) diperoleh nilai rata-rata 23,46. Dengan demikian, mengalami peningkatan sebesar 1,54. Berdasarkan hal tersebut terdapat kenaikan skor pada sesudah pembelajaran (post-test). 
2. Pada pengimajinasian sebelum pembelajaran (pre-test) diperoleh nilai rata-rata 11,53 , sedangkan pada sesudah pembelajaran (post-test) diperoleh nilai rata-rata 16,34. Dengan demikian, mengalami peningkatan sebesar 4,81 . Berdasarkan hal tersebut terdapat kenaikan skor pada sesudah pembelajaran (post-test).

3. Pada penggunaan gaya bahasa sebelum pembelajaran (pretest)diperoleh nilai rata-rata 7,88 , sedangkan pada sesudah pembelajaran (posttest) diperoleh nilai rata-rata 10,16. Dengan demikian, mengalami peningkatan sebesar 2,28. Berdasarkan hal tersebut terdapat kenaikan skor pada sesudah pembelajaran (posttest).

4. Pada pemilihan diksi sebelum pembelajaran (pre-test) diperoleh nilai rata-rata 17,30 , sedangkan pada sesudah pembelajaran (post-test) diperoleh nilai rata-rata 23,65. Dengan demikian, mengalami peningkatan sebesar 6,35 . Berdasarkan hal tersebut terdapat kenaikan skor pada sesudah pembelajaran (post-test).
5. Pada pemilihan rima sebelum pembelajaran (pre-test) diperoleh nilai rata-rata 10 , sedangkan pada sesudah pembelajaran (post-test) diperoleh nilai rata-rata 7,5. Dengan demikian, mengalami peningkatan penurunan sebesar 2,25. Berdasarkan hal tersebut terdapat kenaikan skor pada sesudah pembelajaran (post-test).

Pembelajaran Menulis Puisi Siswa Kelas X-5 SMA Negeri 1 Tukdana Tahun Pelajaran 2016/2017 Berdasarkan Uji-t

Efektif atau tidaknya pembelajaran yang dilaksanakan untuk mengetahui hasil belajar siswa dapat dilihat dari hasil belajar siswa melalui penilaian. Penilaian yang peneliti lakukan adalah tes awal dan tes akhir. Penilaian dilaksanakan di kelas X-5 SMA Negeri 1 Tukdana Tahun Pelajaran 2016/2017. Adapun hasil yang diperoleh adalah sebagai berikut.

Rekapitulasi nilai pre-test dan posttest siswa kelas X-5 SMA Negeri 1 Tukdana Tahun Pelajaran 2016/2017, peneliti uraikan pada tabel berikut.

Tabel 2

Nilai Pre-test dan Post-testMenulis Puisi Siswa Kelas X-5 SMA Negeri 1 Tukdana Tahun Pelajaran 2016/2017

\begin{tabular}{|c|c|c|c|c|c|c|}
\hline \multirow{3}{*}{ No. } & \multirow{3}{*}{ Nama Siswa } & \multicolumn{2}{|c|}{ Nilai } & \multirow{3}{*}{$\mathbf{d}=(\mathbf{Y}-\mathbf{X})$} & \multirow{3}{*}{ Xd (d-Md) } & \multirow{3}{*}{$\mathbf{X}^{2} \mathbf{d}$} \\
\hline & & Pretest & Posttest & & & \\
\hline & & $X$ & $Y$ & & & \\
\hline 1. & Ari Apriyanto & 75 & 95 & 20 & 6,54 & 42,77 \\
\hline 2. & Ayu Erita & 60 & 85 & 25 & 11,54 & 133,17 \\
\hline 3. & Ayunda Velycia & 60 & 90 & 30 & 16,54 & 273,57 \\
\hline 4. & Dasi'ah & 70 & 80 & 10 & $-3,46$ & 11.97 \\
\hline 5. & Er Rudin & 70 & 90 & 20 & 6,54 & 42,77 \\
\hline 6. & Evi Dayanti & 75 & 55 & -20 & $-33,46$ & 1,11 \\
\hline 7. & Iin Sunaesih & 75 & 90 & 15 & 1,54 & 2,37 \\
\hline 8. & Irna & 60 & 75 & 15 & 1,54 & 2,37 \\
\hline 9. & Ita Rahmawati & 70 & 85 & 15 & 1,54 & 2,37 \\
\hline 10. & Lia Erfi Eryana & 70 & 75 & 5 & $-8,46$ & 71,57 \\
\hline 11. & Mistinih & 65 & 90 & 25 & 11,54 & 133,17 \\
\hline 12. & Moch. Azis Ally & 60 & 75 & 15 & 1,54 & 2,37 \\
\hline 13. & Muhammad Gilang. R & 65 & 80 & 15 & 1,54 & 2,37 \\
\hline
\end{tabular}


BAHTERA INDONESIA:

ISSN 2541-3252

Jurnal Penelitian Pendidikan Bahasa dan Sastra Indonesia

\begin{tabular}{|c|c|c|c|c|c|c|}
\hline 14. & Novitasari & 70 & 80 & 10 & $-3,46$ & 11.97 \\
\hline 15. & Nur'asiyah & 70 & 80 & 10 & $-3,46$ & 11.97 \\
\hline 16. & Pandu Dwinata & 45 & 85 & 40 & 26,54 & 704,37 \\
\hline 17. & Riyan Prayoga & 85 & 85 & 0 & $-13,46$ & 181,17 \\
\hline 18. & Riyanto & 75 & 80 & 5 & $-8,46$ & 71,57 \\
\hline 19. & Ropisah & 75 & 95 & 20 & 6,54 & 42,77 \\
\hline 20. & Suhendro Bimantoro & 90 & 75 & -15 & $-28,46$ & 809,97 \\
\hline 21. & Sureni & 70 & 80 & 10 & $-3,46$ & 11.97 \\
\hline 22. & Tasiroh & 65 & 75 & 10 & $-3,46$ & 11.97 \\
\hline 23. & Thomas Suta & 65 & 85 & 20 & 6,54 & 42,77 \\
\hline 24. & Waslam & 70 & 75 & 5 & $-8,46$ & 71,57 \\
\hline 25. & Wira Winengsih & 65 & 85 & 20 & 6,54 & 42,77 \\
\hline 26. & Yuli Aprilianti & 65 & 90 & 25 & 11,54 & 133,17 \\
\hline $\mathbf{N}=$ & Jumlah & 1785 & 2135 & 350 & 0,04 & 2810,11 \\
\hline 22 & Rata-rata & 68,65 & 82,11 & 13,46 & 0,0015 & 108.08 \\
\hline
\end{tabular}

Berdasarkan tabel tersebut, diketahui bahwa nilai rata-rata pre-test68,65 (enam puluh delapan koma enam lima) dan nilai rata-rata post-test82,11 (delapan puluh dua koma sebelas). Dengan demikian nilai ratarata tersebut mengalami kenaikan yakni13,11 (tigabelas koma empat enam).Kemudian untuk mengetahui pembelajaran menulis puisi dengan metode resitasiefektif atau tidak, maka perlu diuji efektivitasnya dengan rumus uji t, adapun langkah-langkah uji t sebagai berikut.

$$
\mathrm{t}=\frac{M d}{\sqrt{\frac{\Sigma X^{2} d}{N(N-1)}}}
$$

Keterangan:

Md : mean dari perbedaan pretest dengan posttest (posttest-pretest)

xd : deviasi masing-masing subjek (d $\mathrm{Md})$

$\Sigma X^{2} d \quad$ : jumlah kuadrat deviasi

$\mathrm{N} \quad$ : subjek pada sampel

d.b. : ditentukan dengan $\mathrm{N}-1$

1. Mencari d

$\mathrm{d}=$ Jumlah post-test - Jumlah pre-test

$$
=2135-1785=350
$$

2. Mencari rata-rata (mean) dari deviasi (d) antara post-test dan pre-test $\mathrm{Md}=\frac{\sum d}{N}$

$=\frac{350}{26}$

$$
=13,46
$$

3. Mencari df dan db dengan rumus

$$
\begin{aligned}
& \text { df }=\text { N-1 } \\
& =26-1 \\
& =25
\end{aligned}
$$

4. Mencari $\mathrm{t}_{0}\left(\mathrm{t}_{\text {hitung }}\right)$.

$$
\begin{aligned}
t_{0} & =\frac{M d}{\sqrt{\frac{\Sigma X d^{2}}{N(N-1)}}} \\
& =\frac{13,46}{\sqrt{\frac{2810,11}{26(26-1)}}} \\
& =\frac{13,46}{\sqrt{\frac{2810,11}{26(25)}}} \\
& =\frac{13,46}{\sqrt{\frac{2810,11}{650}}} \\
& =\frac{13,46}{\sqrt{4,32}} \\
& =\frac{13,46}{2,08} \\
& =6,47
\end{aligned}
$$

5. Menentukan $t_{\text {tabel }}$

Taraf signifikan : $5 \%$ atau $\mathrm{a}=0.05$

Derajat bebas : 25 


$$
\mathrm{t}_{\text {tabel }}=\mathrm{t}(0,05 ; 25)=1,706
$$

Berdasarkan data tersebut, diperoleht $_{\text {hitung }}=6,47$ (enam koma empat tujuh) dan $t_{\text {tabel }}=1,706$ (satu koma tujuh kosong enam) dengan derajat bebas (db) 25 (duapuluh lima), dan taraf signifikan 5\% a = 0,05. Karena $t_{\text {hitung }}>t_{\text {tabel }}(6,47>1,706)$, maka Ho ditolak dan Ha diterima. Dengan demikian dapat disimpulkan bahwa metode resitasi efektif dalam pembelajaran menulis puisi siswa kelas X-5SMA Negeri 1 TukdanaTahun Pelajaran 2016/2017.

Efektivitas Metode Resitasidalam Pembelajaran Menulis Puisi Siswa Kelas X-5 SMA Negeri 1 Tukdana Tahun Pelajaran 2016/2017 Berdasarkan Kriteria Ketuntasan Minimal (KKM)
Efektivitas metode resitasidapat juga diketahui berdasarkan nilai Kriteria Ketuntasan Minimal (KKM) yang diperoleh siswa dalam satu kelas sesuai dengan KKM yang telah ditentukan sekolah. KKM mata pelajaran Bahasa Indonesia SMA Negeri 1 Tukdana yaitu 75 dengan presentase KKM $75 \%$ oleh karena itu metode resitasiakan efektif apabila siswa memperoleh nilai $\geq 75$ dan persentase pencapaian KKM siswa dalam satu kelas mencapai > $75 \%$ nilai hasil post-test yang diperoleh siswa kelas X5 SMA Negeri 1 Tukdana dalam pembelajaran menulis puisi dengan metode resitasiTahun Pelajaran 2016/2017. Berdasarkan pencapaian KKM adalah sebagai berikut.

\section{Tabel 3}

Nilai Post-testSiswa Kelas X-5 SMA Negeri 1 Tukdana

Tahun Pelajaran 2016/2017 Berdasarkan Pencapaian Kriteria Ketuntasan Minimal (KKM)

\begin{tabular}{|c|c|c|c|c|c|}
\hline No. & Nama Siswa & KKM & $\begin{array}{l}\text { Tes Akhir } \\
\text { (Posttest) }\end{array}$ & $\begin{array}{c}\text { Kategori } \\
\text { Nilai }\end{array}$ & Keterangan \\
\hline 1. & Ari Apriyanto & 75 & 95 & Baik Sekali & Tuntas \\
\hline 2. & Ayu Erita & 75 & 85 & Baik & Tuntas \\
\hline 3. & Ayunda Velycia & 75 & 90 & Baik Sekali & Tuntas \\
\hline 4. & Dasi'ah & 75 & 80 & Baik & Tuntas \\
\hline 5. & Er Rudin & 75 & 90 & Baik Sekali & Tuntas \\
\hline 6. & Evi Dayanti & 75 & 55 & Kurang & Tidak Tuntas \\
\hline 7. & Iin Sunaesih & 75 & 90 & Baik Sekali & Tuntas \\
\hline 8. & Irna & 75 & 75 & Cukup & Tuntas \\
\hline 9. & Ita Rahmawati & 75 & 85 & Baik & Tuntas \\
\hline 10. & Lia Erfi Eryana & 75 & 75 & Cukup & Tuntas \\
\hline 11. & Mistinih & 75 & 90 & Baik Sekali & Tuntas \\
\hline 12. & Moch. Azis Ally & 75 & 75 & Cukup & Tuntas \\
\hline 13. & Muhammad Gilang. R & 75 & 80 & Baik & Tuntas \\
\hline 14. & Novitasari & 75 & 80 & Baik & Tuntas \\
\hline 15. & Nur'asiyah & 75 & 80 & Baik & Tuntas \\
\hline 16. & Pandu Dwinata & 75 & 85 & Baik & Tuntas \\
\hline 17. & Riyan Prayoga & 75 & 85 & Baik & Tuntas \\
\hline 18. & Riyanto & 75 & 80 & Baik & Tuntas \\
\hline 19. & Ropisah & 75 & 95 & Baik Sekali & Tuntas \\
\hline 20. & Suhendro Bimantoro & 75 & 75 & Cukup & Tuntas \\
\hline 21. & Sureni & 75 & 80 & Baik & Tuntas \\
\hline 22. & Tasiroh & 75 & 75 & Cukup & Tuntas \\
\hline
\end{tabular}




\begin{tabular}{|l|l|l|l|l|l|}
\hline 23. & Thomas Suta & 75 & 85 & Baik & Tuntas \\
\hline 24. & Waslam & 75 & 75 & Cukup & Tuntas \\
\hline 25. & Wira Winengsih & 75 & 85 & Baik & Tuntas \\
\hline 26. & Yuli Aprilianti & 75 & 90 & Baik Sekali & Tuntas \\
\hline
\end{tabular}

Untuk mengetahui persentase $\mathrm{Ho}=\mathrm{t}_{0}<\mathrm{t}_{\text {tabel }}$ ketercapaian KKM dapat dilakukan dengan cara penghitungan sebagai berikut.

$N$

$=\frac{\text { Jumlah siswa yang mencapai KKM }}{\text { Jumlah siswa keseluruhan }} \times 100 \%$

$\frac{25}{26} X 100 \%=96,15 \%$

Berdasarkan data tersebut, diperoleh ketercapaian KKM keseluruhan siswa berjumlah 26 dalam satu kelas yang mencapai KKM 25 siswa atau dengan kata lain jumlah presentase siswa dalam satu kelas yang telah mencapai nilai KKM yaitu jadi 96,15\%. Dengan demikian dapat disimpulkan bahwa Metode resitasi efektif dalam pembelajaran menulis puisi siswa kelas X-5 SMA Negeri 1 Tukdana Tahun Pelajaran 2016/2017.

\section{Pembuktian Hipotesis}

Hipotesis dalam penelitian ini adalah sebagai berikut:

\section{E. SIMPULAN}

Hasil penelitian dan analisis data yang dilakukan oleh peneliti mengenai hasil belajar siswa menggunakan metode resitasi dalam menulis puisi di SMA Negeri 1 Tukdana Tahun Pelajaran 2016/2017, menghasilkan beberapa simpulan berikut.

1. Kemampuan menulis puisi siswa kelas X SMA Negeri 1 Tukdana Tahun Pelajaran 2016/2017 sebelum pembelajaran dengan metode resitasi,hasil rata-rata keseluruhan kelas yang didapat 68,65. Hasil tersebut menunjukkan bahwa kemampuan siswa kelas X-5 SMA Negeri 1 Tukdana dalam menulis puisi termasuk kategori Cukup.
$\mathrm{Ha}=\mathrm{t}_{0}>\mathrm{t}_{\text {tabel }}$

Metode resitasi tidak efektif dalam pembelajaran menulis puisi siswa kelas $\mathrm{X}$ SMA Negeri 1 Tukdana 2016/2017.

: Metode resitasiefektif dalam pembelajaran menulis puisi siswa kelas $\mathrm{X}$ SMA Negeri 1 Tukdana 2016/2017.

Berdasarkan data tersebut, diperoleht $\mathrm{hitung}_{\text {}}=$ 6,47 (enam koma empat tujuh) dan $t_{\text {tabel }}=$ 1,706 (satu koma tujuh nol enam) dengan derajat bebas (db) 25 (duapuluh lima), dan taraf signifikan $5 \% \mathrm{a}=0,05$. Karena $\mathrm{t}_{\text {hitung }}$ $>t_{\text {tabel }}(6,47>1,706)$, maka Ho ditolak dan Ha diterima. Dengan demikian dapat disimpulkan bahwa metode resitasi efektif dalam pembelajaran menulis puisi siswa kelas X-5SMA Negeri 1 TukdanaTahun Pelajaran 2016/2017.

2. kemampuan menulis puisi siswa kelas $\mathrm{X}$ SMA Negeri 1 Tukdana Tahun Pelajaran 2016/2017 sesudah pembelajaran dengan metode resitasi, hasil rata-rata keseluruhan kelas yang didapat 82,11. Hasil tersebut menunjukkan bahwa kemampuan siswa kelas X-5 SMA Negeri 1 Tukdana dalam menulis puisi termasuk kategori Baik.

3. Berdasarkan hasil penelitiandiperoleht $t_{\text {hitung }}=6,47$ dan $\mathrm{t}_{\text {tabel }}=1,706 \mathrm{denganderajatbebas}(\mathrm{db})$ 25 (duapuluh lima), dantarafsignifikan $5 \% \mathrm{a}=0,05$. Karena $\mathrm{t}_{\text {hitung }}>\mathrm{t}_{\text {tabel }}(6,47$ $>$ 1,706), maka Ho ditolak dan $\mathrm{Ha}$ diterima. Sedangkan ketercapaian KKM keseluruhan siswa berjumlah 26 dalam satu kelas yang mencapai 
KKM 25 siswa atau dengan kata lain jumlah presentase siswa dalam satu kelas yang telah mencapai nilai KKM yaitu jadi $96,15 \%$. Dengan demikian dapat disimpulkan bahwa Metode

\section{F. DAFTAR PUSTAKA}

Arikunto, Suharsimi. 2010. Prosedur penelitian suatu pendekatan praktik. Jakarta. Rineka Cipta.

Asmani, Jamal Ma'mur. 2011. Tujuh Tips Aplikasi Pakem (Pembelajaran Aktif, Kreatif, Efektif, dan Menyenangkan). Jogjakarta: Diva Press.

Atar, Semi M. 2007. Dasar-dasar Ketrampilan Menulis. Bandung. Angkasa.

Djamarah, S.B. dan Zain. 2010. Strategi Belajar Mengajar. Jakarta: Rineka Cipta.

Hamdani. 2011. Strategi Belajar Mengajar. Bandung: Pustaka Setia.

Hamid, Moh. Sholeh. 2014. Metode EDU Tainment. Jogjakarta: DIVA Press.

Heriawan, Adang. dkk. 2012. Metodologi Pembelajaran Kajian Teoretis Praktis. Banten. LP3G (Lembaga Pembinaan dan Pengembangan Profesi Guru).

Janah, Nurlaela Roikhatul. 2015. Skripsi Pembelajaran Cerita Pendek dengan Metode Quantum Writing di Kelas X SMA Negeri 1 Juntiyuat Indramayu Tahun Pembelajaran 2015/2016. Indramayu: UNWIR.

Kosasih, E. 2014. Dasar-Dasar Keterampilan Berbahasa. Bandung: CV. Yrama Widya. resitasi efektif dalam pembelajaran menulis puisi siswa kelas X-5 SMA Negeri 1 Tukdana Tahun Pelajaran 2016/2017.

Kosasih, E. 2015. Strategi Belajar dan Pembelajarn Implementasi Kurikulum 2013. Bandung: Yrama Widya.

Nazir, Moh. 2011. Metode Penelitian. Bogor. Grahalia Indonesia.

Nurgiyantoro, Burhan.2014. Penilaian Pembelajaran Bahasa Berbasis Kompetensi.Yogyakarta. BPFEYogyakarta.

Nurjamal, Daeng. dkk. 2015. Keterampilan Berbahasa. Bandung: Alfabeta.

Puspasari, Aulia Perbiana. 2013. Skripsi Kemampuan Menulis Puisi dengan Teknik Pemberian Tugas/Resitasi pada Siswa Kelas VIII SMPN 2 Tanggerang Selatan. Jakarta: Universitas Islam Negeri Syarif Hidayatullah.

Pusat Bahasa. 2012. Kamus Besar Bahasa Indoesia. Jakarta: PT Gramedia Pustaka Utama.

Rokhmansyah, Alfian. 2014. Studi dan Pengkajian Sastra Perkenalan Awal Terhadap Ilmu Sastra. Yogyakarta: Graha Ilmu.

Rusmana. 2012. Model-model Pembelajaran (Mengembangkan Profesionalisme Guru). Jakarta: Rajawali Press.

Riduwan. 2015. Dasar-dasar Statistika. Bandung: Alfabet.

Sudjana. 2005. Metode Statistika. Bandung: Tarsito.

Sugiyono. 2013. Metode Penelitian Pendidikan Pendekataan Kuantitatif, 
BAHTERA INDONESIA:

Kualitatif, dan $K$ \& $D$. Bandung: Alfabeta.

Tarigan, Henry Guntur. 2008. Menulis Sebagai Suatu Keterampilan Berbahasa. Bandung: Angkasa.

Tarigan, Henry Guntur. 2009. Dasar-dasar Kurikulum Bahasa.

Bandung:Angkasa.

Tarigan Hanry Guntur. 2015. PrinsipPrinsip Dasar Sastra. Bandung:Angkasa.

Tim Edukatif. 2006. Kompoten Berbahasa Indonesia untuk SMA Kelas X. Jakarta: Erlangga.
Uno, Hamzah B. 2012. Perencanaan Pembelajaran. Jakarta: Bumi Aksara.

Wati, Windah. 2013. Skripsi Efektivitas Penggunaan Metode Resitasi dalam Pembelajaran Menyimak Berita pada Siswa Kelas VII SMP Negeri 5 Kota Cirebon Tahun Pelajaran 2012/ 2013. Cirebon: Unswagati.

Waluyono, Herman J. 2002. Apresiasi Puisi. Jakarta. PTGramesia Pustaka Utama.

Wardoyo, Sigit Mangun. 2013. Teknik Menulis Puisi. Yogyakarta: Graha Ilmu. 